\title{
Anne Arketipinin Didem Madak'ın Şiirlerindeki İzleri
}

\section{Traces of Mother Archetype in Didem Madak's Poems}

\author{
Ece Serrican Kabalci*
}

"Dünyaya bile bir dünya anne lazım."

Didem Madak

Öz

Carl Gustav Jung’un, “Analitik Psikoloji” adını verdiği psikoloji çalışmaları içerisinde yer alan arketipler, geçmişten günümüze aktarılan davranış kalıplarıdır. "İlk örnek/model" olarak kabul edilen arketipler, insanoğlunun ortak/kolektif bilinç dışında yer alan, bireysel olanı evrensele bağlayan kodlardır. Bu kodlardan biri olan anne arketipi ise, insan hayatında iz bırakan bir özelliğe sahiptir.

Anne arketipinin izlerinin takip edilebildiği bir şair olan Didem Madak, küçük yaşlarda annesini kaybetmiş ve kırklı yaşlarının başında henüz üç yaşındaki kızını ardında bırakarak hayata gözlerini yummuştur. Annesizliğin eksikliğini ve acısını eserlerine yansıtmış olan Didem Madak'ın şiirlerinin toplandığı üç eser: Grapon Kâğttlart (2000), Ah'lar Ăgacı (2002) ve Pulbiber Mahallesi (2007) başlıklarını taşır. Şiirleri gibi kitaplarını da farklı kişilere ithaf eden şairin; Grapon Kâğıtları'nda on sekiz, Ah 'lar Ağacı'nda dokuz, Pulbiber Mahallesi'nde on beş şiiri bulunur. Pulbiber Mahallesi’nin sonunda “Ardından” başlı̆̆ altında, şairin kitaplarında yer almayan fakat dergilerde yayımlanmış olan dört şiirine, yakın dostu Müjde Bilir'in kaleminden son günlerinin anlatıldığı metne ve yazdığı son şiir olan 128 Dikişli Şiir'e yer verilmiştir. 
Bu çalışmada söz konusu üç kitapta bulunan tüm şiirler, Carl Gustav Jung tarafından çerçevesi çizilen arketipsel eleştiri yöntemi esas alınarak incelenmiş, anne arketipi merkez alınarak elde edilen bulgular değerlendirilmiştir. Yapılan çalışma sonucunda Jung'un, her bireyin ortak/kolektif bilinç dışında yer aldığını vurguladığı arketiplerden olan anne arketipinin, Didem Madak'ın şiirlerinde de etkin bir şekilde kullanıldığı görülmüştür. Böylece şairin arketiplerden yararlandığı ve şiirleri sayesinde bilinç dışındakini bilinç düzeyine çıkarabildiği sonucuna ulaşılmıştır. Çalışma sonucunda elde edilen tüm bulgular değerlendirildiğinde, edebî eserlerde bireysellikten evrenselliğe uzanan köprünün arketipler sayesinde kurulabileceği görülmüştür.

Anahtar sözcükler: Didem Madak, Carl Gustav Jung, arketip, şiir, anne

\begin{abstract}
Archetypes, which are included in the psychology studies that Carl Gustav Jung called "Analytical Psychology", are behavioral patterns that have been transferred from past to present. The archetypes, which are accepted as "primary pattern/ model", and which exist outside of humans' mutual/collective unconscious, are the codes that connect the individual to the universal. One of these codes, the mother archetype, has a trait in human life.

Didem Madak, a poet whose "mother archetype" could be traced, lost her mother at a young age and left her three-year-old daughter behind in her forties. Thus, Didem Madak has reflected pain of being motherless to her works. The three works that collect Didem Madak's poems are titled as Grapon Kâğıtları (2000), Ah'lar A $\breve{g} a c ı$ (2002) and Pulbiber Mahallesi (2007). The poet dedicated her poems to different people just as she did in her books. There are eighteen poems in Grapon Kâğtlart, nine in Ah'lar A $\breve{g} a c l$, and fifteen in the Pulbiber Mahallesi. At the end of the Pulbiber Mahallesi; there are four poems which were not included in the books of the poet, but published in journals under the title "Ardından", the text of her last days from the pen of her close friend Müjde Bilir, and the last poem she wrote, and her last poem named "128 Dikişli Şiir". In this study, all the poems in the three books were examined based on the archetypal criticism method which was framed by Carl Gustav Jung and the findings obtained by taking the mother archetype in the center were evaluated. As a result of the study, it has been shown that the "mother archetype", which has been expressed by Jung as a "mutual/collective unconscious archetype" in each individual, is widely seen in Didem Madak's poems. Thus, it was concluded that the poet benefited from the archetypes and that she could raise the unconscious to the level of consciousness through her poems. When all the findings of the study were evaluated, it was seen that the bridge extending from individuality to universality in literary works can be established by archetypes.
\end{abstract}

Keywords: Didem Madak, Carl Gustav Jung, archetype, poem, mother 


\section{Giriş}

Edebiyat incelemelerinde kullanılan psikoloji biliminin verileri, çözümleme çalışmalarına farklı bir bakış açısı getirmesi bakımından önemlidir. Esere ve yazara yönelik farklı bir bakış açısı sunan psikoloji biliminin temelini ise psikanaliz oluşturur. Psikanaliz alanında öncü bir isim olan Sigmund Freud'un kuramından ayrılarak kendine özgü bir ekol oluşturan ve buna "Analitik Psikoloji” adını veren kişi Carl Gustav Jung’tur. Jung'un, metin çözümlemelerine kaynak sağlayan düşüncelerinden biri arketiplerdir. Arketipler, kökeni geçmişten günümüze dek uzanan ve her insanın ortak/kolektif bilinç dişında yatan ilk örnek/modellerdir.

Jung'a göre kişisel bilinç dışı, bireyin yaşamından kaynaklanan, unutulmuş, bastırılmış ve bilinç dışı yoluyla algılanmış şeyleri kapsar. Ortak bilinç dışı ise; tarihî çağa, topluma ve ırka bakmaksızın dünyanın varoluşundan beri görülen ve insanoğlunun evrensel durumlara karşı gösterdiği kalıpsal tepkileri içerir. Bu nedenle ortak bilinç diş1 her bireyde doğuştan bulunur ve kişisel deneyimlerden bağımsızdır (Jung, 1997, s. 33).

Jung'un arketip kavramıyla kastettiği anlama ilk defa Platon'da rastlanır. Ancak Jung, Platon' dan farklı olarak arketiplerin sadece gelenek, dil ve göçle yaygınlaşmadığını; herhangi bir zamanda, herhangi bir yerde ve dış etken olmadan kendiliğinden doğabildiklerini göstermiştir (Jung, 2015a, s. 121). Platon, "idea" ya da "eidos" kavramiyla ilksel tiplere ve ortak imgelere işaret eder ve bunları yüce tamlık örneği olarak tanımlar. Arketipler ise; ortak mitlerden, yaşantılardan ve bilinç dışı kaynaklı ürünlerden oluşan, insanda hazır olarak bulunan kodlardır. Bu yüzden arketipler, "a priori” (önsel) kavramlar olarak kabul edilir ve kişisel yaşantıdan bağımsız olduklarından bireyin ölümüyle yok olmazlar (Bahadır, 2010, ss. 86-88).

Jung'a göre, davranış kalıpları olan arketipler, insan ruhu üzerinde gizli bir güce sahiptir. Tüm insanlığa ait olan bu ilksel imgeler, kişisel yazgıyı insanlığın yazgısına dönüştürür (Jung, 2015b, s. 56). Korku, tehlike, üstün bir güce karşı mücadele, nefret, aşk, doğum, ölüm, aydınlığın gücü, karanlığın korkutuculuğu, cinsler arası ilişkiler gibi insanlığın evrensel tipteki olayları karşısında gösterilen tüm reaksiyonlar, kolektif bilinç dışının içeriğini oluşturur (Sambur, 2015, s. 89). Ortak bilinç dışında bulunan arketipler, kişisel deneyimlerin ürünü değildir. Her insanda doğuştan bulunur ve soygelişimsel izler taşır. $\mathrm{Bu}$ nedenle, insanoğlunun ortak mirasına sahip olan yazar tarafından oluşturulan eserlerde de ortaya çıkar. Edebî eserlere uygulanan arketipsel eleştiri yöntemi sayesinde, yazarın öznel dünyası ve yazılan eser üzerinden arketipsel mirasın nasıl kullanıldı̆̆ı araştırılır.

Jung, bu miras içerisinde persona, gölge, anima, animus, anne, yaşlı bilge ve hilebaz arketiplerine önem vermektedir. Persona, kişinin dünya ile ilişkilerini sağlayan bir maskedir. Gölge, vahşi istek ve duyguları kapsayan ilkel yöndür ve kişi tarafından bastırılması gerekir. Erkeğin içindeki dişil özellikler anima, kadının içindeki erillik ise animustur. Doğurganlık ve bereketin temsilcisi olan anne, olumlu ve olumsuz özellikleri aynı anda içerebilir. Aynı zamanda kişisel anne, büyükanne, üvey anne, kayınvalide ya da bakıcı kadın şeklinde belirebilir. Akıl ve sezgi gücüyle yol gösterici olan yaşlı bilgedir. 
Hilebaz ise, kurnaz ve alaycı yönüyle eserlerde tanınır (Gürol, 1977, ss. 15-18). Bireysel olanı evrensele aktaran ve bakış açısını zenginleştiren arketiplerin edebî eserlerdeki izini sürmek ve onları ortaya çıkarmak, ortak bir paydada buluşmayı sağlar.

Jung'un ön plana çıkardığı temel arketiplerin dışında, hayattaki tipik durum sayısı kadar arketip vardır. Arketipler başlangıçta belli bir algı ve eylemde bulunma durumunu temsil eden içeriksiz biçimler hâlinde ortaya çıkarlar, daha sonra sayısız tekrarlar sayesinde psişik yapıya kazınırlar. Böylece atalardan devralınan mirası oluştururlar (Hall \& Nordby, 2016, s. 41). Bu ortak miras sayesinde arketipler, evrensel ve özdeş yapılar hâline gelerek tüm insanlığa ait ortak davranış kalıplarını ortaya çıkarırlar. Bu nedenle sınıf, din, ırk, coğrafi konum, tarih gibi farklılıklardan bağımsız olarak benzer düşüncelere, imgelere, duygu ve davranışlara yol açarlar. Edebiyatta işlenen mit ve masalların tüm insanlardaki ortak motiflerle uyuşması, her çocuğun doğar doğmaz "anne" dediği koruyucu bir kadına bağlanması, her erkek ve kadının fiziksel ve ruhsal olarak karşıt cinslere ihtiyaç duyması gibi örnekleri Jung, arketipik gerçekleşim delilleri olarak kabul eder (Bahadır, 2010, ss. 88-92).

Her duruma uygun bir arketip ile karşılaşılsa da, Jung'un temel arketipler olarak dile getirdiği arketipler arasında özellikle anne arketipinin önemli bir yeri vardır. Çünkü her bireyde kalıtımla birlikte ortaya çıkan ve ilk izleri doğumdan itibaren takip edilebilen bir anne arketipi bulunur. Ortak bilinç dışına seslenen arketipler içerisinde yer alan anne arketipi, her bireyde somut olarak görülebilen anne sevgisi ile ortaya çıkmaktadır.

Her doğan bebekte, kalıtım yoluyla gelen bir anne arketipi vardır. Önceden tasarlanmış bu anne imgesi; gerçek annenin belirmesiyle, davranışlarıyla ve bebeğin onunla olan ilişkileri ve deneyimiyle esas anne imgesine dönüşür (Hall \& Nordby, 2016, s. 42). Böylece her çocuk kendini koruyan, besleyen ve seven kişi ile yani annesi -ya da anne yerine geçen bir figür- ile bağ kurarak büyür. Bu yüzden kişinin "anne" ilişkisini tanımasını sağlayan doğuştan gelen yeteneğe anne arketipi adı verilir. Anne arketipi ilk olarak anneye, anne yoksa farklı bir kişiye yansıtılır. Zihindeki anne arketipinin ihtiyaçları gerçek anne tarafından karşılanmadığında huzur arayışı ortaya çıar (Ukray, 2015, ss. 124-125).

Jung'a göre, anneye -gerçek anne ya da anne figürü- olan bağl1lık, anne arketipine olan bağl1lıktır. Çünkü anne arketipinin özellikleri "annelik" ile ilgilidir. Tüm arketiplerde olduğu gibi anne arketipinin de çift kutuplu bir özelliği vardır. Bu nedenle, olumlu ve olumsuz yönleri bir arada bulunur. Olumlu yönünde bilgelik, ruhsal yücelik, bakıp büyüten olma gibi özellikler vardır. Olumsuz yönünde ise; gizli saklı olan, korku uyandıran ve zehirleyen özellikler vardır. Anneye olan bağlllık kız ve erkek çocuklarda da farklı şekillerde ortaya çıkar. Oğlunu serbest bırakmayarak himayesinde tutan bir anne, anne arketipinin olumsuz yönünü temsil eder. Olumlu yönü temsil eden bir anne ise, oğlunu serbest bırakarak gelişmesine yardımcı olur. Kızlarda anne arketipi, dişi içgüdülerin aşırı güçlenmesi ya da yok olana kadar zayıflaması şeklinde ortaya çıkar. İçü̈düler güçlendiğinde kız kendi kişiliğinin bilincinde olmaz, zayıflaması sonucunda ise içgüdüler anneye yansit1lır (Jung, 2012, 22-25). Her iki durumda da, anne arketipinin bireyin 
hayatı üzerinde etkili olduğu görülür. Anneyle kurulan bir bağa sahip olma ya da ondan yoksun olma hâli, bilinç dışında bulunan anne arketipini faaliyete geçiren ve gizli ya da açık bir şekilde onun dışa vurumunu gerçekleştiren bir durumdur. Arketipin farkına varılarak onun nasıl tezahür ettiğinin araştırılması da arketipsel eleştiri kapsamında ele alınan çözümleme çalışmalarını oluşturmaktadır. Söz konusu çözümleme çalışmaları, birçok alana olduğu gibi edebiyat alanına da kaynaklık etmektedir.

\section{Didem Madak'ın şiir dünyası}

İzmir doğumlu olan Didem Madak, annesini çocuk yaşta kaybetmiştir. Bu nedenle onun yokluğunu her zaman içinde hissetmiş̧tir. Hayata karşı tek başına mücadele ederken yalnızlığını ve annesizliğini dizelerinde dışa vurmuştur. Şairin, şiire olan ilgisi annesi Füsun'un ölümünden sonra başlamıştır. "Annemden bana kalan tek miras bir sihirdir. Onu ne zaman çok özlesem hep bir şiir yazdım." diyen şair, annesinin kaybını şiirle doldurabileceğini düşünerek şiir yazmaya başlamıştır (Bilir, 2015, s. 26). Şairanelikten ziyade samimi bir üslupla, gündelik hayata dair ayrıntılarla ve tüm doğallığıyla şiirler yazmıştır. Hayatın genel ritmi üzerinde ilerleyen dizeleri, kızı Füsun'un doğumundan sonra -annesinin ismi de Füsun'dur- duraklamış, şiir yazamamıştır. Bu durumu, 2009 yllında bir arkadaşına gönderdiği elektronik postada, kızına hitap ederek şu şekilde dile getirir:

Canım kızım,

Sana mektup yazacağım. Çünkü artık başka bir şey yazamıyorum. Bu konuda pek de dertli değilim doğrusunu istersen. Sen bana belki bugüne kadar yazd1ğımdan başka türlü bir yazı yazmayı öğretirsin. Kendimi bir sonbahar ağacı gibi hissediyorum. Mutlu bir sonbahar ağacıyım ben. Yere düşen yapraklarımı eğilip topluyorum. Saçıma tutuyorum. Bakın yakışmış mı diye soruyorum. Sonra yaprakları havaya savuruyorum. Ben iki kişilik bir kabilenin me isimli kölesiyim. Çünkü sen acıktı̆̆ında me diye ağlıyorsun ve bu ismimi seviyorum reis!

Canım kızım, cehaletimden şair oldum... Annesizlikten. Sen sakın şair olma! (Yücel, 2015, s. 100).

Şair, Grapon Kâğıtları'nda' okuyucuyu çocukluğunun anılarına götürür. Ah'lar A ğacı'nda ${ }^{2}$, hayatla olan hesaplaşmasının ve her şiirine hâkim olan anne özlemi üzerinden yaşadığı acıların ve kırgınlıkların şiirini yazar. Pulbiber Mahallesi'nde ${ }^{3}$ şiirin dili gündelik hayata yaklaşır. Tüm şiirlerinde hayatını samimiyet ve cesaretle anlatır. Didem Madak, 2002 yılında gerçekleştirdiği bir söyleşide, şiir anlayışını şu şekilde özetler:

Benim hayatımla ve kadın oluşumla ilgili çözemediğim bazı meselelerim var, bu meselelerle samimiyet ve cesaretle boğuşuyorum hâlâ. Bütün bunlar yokmuş gibi davranıp kitabî şiirler yazamam. Şiirlerim ütüsüz ve buruşuk gezdirdiğim ruhumun diyeti bence. $\mathrm{Bu}$ yüzden hepsi benden parçalarla dolu. $\mathrm{Bu}$ yüzden biraz 'kadınsı', durup dururken bağıran şiirler (Bilir, 2012). 
Didem Madak’ın şiirlerinde tüm izlekler iç içe geçmiştir. Kadınların gündelik yaşamı üzerinden aşk, ölüm, sınıfsal çelişkiler, yalnızlık ve inanç sıklıkla işlenmiştir. Kadın olmanın zorlukları ve kendine ait bir hayat kurabilmek için gösterilen çaba, her şiirinde kendini göstermiştir (Alp, 2012, s. 184). Didem Madak’ın şiirleri; bir kadının gündelik ev içi yaşamından alınan "haraşo örgüler”, "eski tül perdelerden gelinlikler”, "1slak unutulmuş taş bezi", "uçlarından çile damlayan yorgun çamaşırlar", "kalbinin raflarına dizdiği rengârenk reçeller”, "yamanan aşk”, "çoktandır öksüz kalan mutfak”, "kalbim ucu kararmış tahta kaşık” gibi benzetmeler, metaforlar ve imgelerle doludur. Hayata ve egemen erkek söylemine karşı eleştirel ve sorgulayıcı bir şiir sesi getirdiği eserlerinde, gülümseten bir kara mizah ve ironi de dikkat çeker (Yücel, 2011, s. 16).

Yaşayan günlük dili tüm canlılığıyla şiire dönüştüren Didem Madak’ın, Grapon Kâğıtları'nın arka kapağında yer alan sözleri, şiirlerinin hayatının özü olduğunu ortaya koyar. Şiirlerinde yer alan şahıs ve mekânların gerçek olduğunu, kahramanlarını kedilerin, kadınların, muhabbet kuşlarının ve bolca gözyaşının oluşturduğunu belirtir. Sonrasında ise, mizahi üslubuyla, şiirden hazzetmeyenlerin Grapon Kâğıtları'nı yılbaşı ve diğer önemli günlerde evi süslemek için kullanabileceğini ya da bir ruh çağırma seansında, inatçı ruhlara seslenen uyduruk şarkılar olarak mırıldanabileceğini dile getirir (s. 70).

Didem Madak, 2003 yılında katıldığı bir panelde yaptığı konuşmada kendi hayatını ve şiir serüvenini anlatır. Annesinin ölümünün ardından bir kadının gölgesinde büyümediğini belirtir. Babası tekrar evlenince evden kurtulmak amacıyla on dokuz yaşındayken evden kaçar ve evlenir. Felsefe öğrencisi olan kocasından ayrıldıktan sonra maddi sıkıntılar yaşar ve bir bodrum katına taşınır. İlk şiir çalışmalarına, rutubetine dayanılabildiği sürece iyi bir yazım alanı olan bodrum katında başlar (Madak, 2015, ss. 355-356). Hayatının bu dönemini Grapon Kâğıtları'ndaki Kedilerin Alışkanlıkları adlı şiirinde anlatır: “Ardımda kırık bir ayna/ Üvey anneleri hayatımın./ Batsın diye güneşe tempo tutan o kız çocuğu.../ Evden kaçışımın pembe spor ayakkabıları vardı./ Hüzün neydi sanki o zaman/ Artık kullanılmayan dikiş makinesi annemden kalma./ Ölüm neydi sanki o zaman/ Bir önseziden başka./ Evden kaçabilirsin çocuk,/ ama kaderden asla!” (s. 57).

Üvey annesini ve özellikle babasını ardında bırakarak kaçtığı ev, hayatının dönüm noktası olur. Baba sevgisizliğin, ilgisizliğin ve mutsuzluğun sembolü hâline gelir. Fotoğraflardan çıkarılan bir adam olan babası, Grapon Kâğıtları'ndaki Mutsuza Kim Bakacak? şiirinde tekrar belirir: "Mavi kareli gömleğiyle hatırladıkça babamı/ Kırpıp kırpıp fotoğrafları, döküyorum başımdan aşağı/ Sanırım ben assolist olmuşum maviş anne/ Şimdi mutluyum/ Geçmişini yok mu ettin kızım diye soran/ Bir babadan kurtuluşumu kutluyorum/ Babama söyle, o gelmesin maviş anne" (s. 21).

Evden kaçış, mutsuz bir evlilik ve bu sürecinin ardından gelen boşanma; Didem Madak’1 manevi olarak yalnızlığa iter. Kardeşi ve arkadaşları her zaman yanındadır, fakat onun kimsesizliğinin kaynağı annesinden yoksun olmasıdır. Grapon Kâğıtları'ndaki Kurabiye şiirinde: "Zaman zaman çok yalnızım Kalbiye/ Arsız sarmaşıklar gibi her sabah/ Bıkmadan tırmanıyorum güneşin tahta perdesine/ Mor çiçeklerle açılmak için 
dünyaya." (s. 24) şeklinde kaleme aldığı dizeler, yaşadığı yalnızlığa ve hayata karşı tek başına verdiği mücadeleye işaret eder. Hayatındaki yalnızlı̆̆ ve bitmeyen özlemini aynı kitabında yer alan Yüzüm Güvercinlere Emanet'te şu şekilde dile getirir: "Benimse yüreğim/ Koltuk altına sıkıştııılmış, / Yenik bir tavla maçı ertesiydi./ (...) Bir gül uzatırdı çocuklardan biri/ Ellerimden güle yalnızlık batardı/ İçi bulanırdı yalnızlı̆̆ımın/ Kusardı serseriliğini en görkemli meydana" (ss. 28-31).

Ah 'lar Ağacı kitabına adını veren aynı başlıklı şiir, şairin hayatındaki zorluklara ve canını yakan her şeye karşı ünlediği bir "ah", bir ağıttır. Kendisiyle yapılan söyleşide, Grapon Kâğıtları'ndaki şiirleri yazdıktan sonra, uzun bir süre şiir yazamadığını belirtir. İşte o dönem, sürekli "ah" dediği zamanlardır. Bu nedenle de çevresi tarafından sık sık uyarılmıştır. Hatta kendisine: "Ah denmez, af denir." şeklinde öğütler verenler de çıkmıştır (Bilir, 2012). Kendi acılarıyla birlikte aslında herkesin dertlerini, üzüntülerini ve hayal kırıklıklarını "ah"larıyla birlikte bir ahlat ağacına dökmüştür: "Ahlat ahların ağacıydı/ Yaşlanmaya başlayanların,/ İtiraf edilememiş aşkların,/ Evde kalmış kızların./ Ahlat ahların ağacıydı,/ Cezayir nasıl cezaların ülkesiyse,/ Öyleydi işte" (s. 20).

Ah'lar A ğacı'ndaki Müsveddeler şiiri, hayatını ve kendisini anlatmaktan yorgun düşmüş bir kadının serzenişlerini içerir. Bu yorgunluğunu şu dizelerinde dile getirir: "Anlatarak bitiriyorum hayatımı/ Bilmiyorum başka nasıl bitirilir bir hayat/ Bir çiçek çizdim bu akşam avcuma/ İsmini her şey koydum./ Simli ojeler sürdüm yalnızlıktan sıkıldığımdan./ Müsveddesi gibi şimdi tırnaklarım/ Yıldızlı bir gecenin” (s. 53).

Üçüncü şiir kitabı olan Pulbiber Mahallesi, yalnızlığından daha az şikâyet ettiği bir kitaptır. Hayatının bu döneminde mahalle sakinlerine ve sevdiği insanlara sarılır. Yine de içten içe yaşadığ 1 yalnızlığını, farklı şekillerde dile getirmekten çekinmez. Bu yüzden, Hatalı Teşbihler şiirinde kedisi Zeyna -şiir kedisi- ile dertleşirken kalabalıklar ve aydınlıklar içindeki yalnızlığını dile getirir: "Zeyna gölgesini bir başkası sanıp oynuyordu, ben de/ Bir başkası sanıp şiir yazıyordum./ Bir aydınlanma ruhu içinde felaket yalnızdık./ ( ...) Elektrik direklerini salladığımda dolunaylar dökülürdü/ Kırılmazdı hiç, hiç kırılmazdı/ Sofranın ortasına koyardık parlak parlak/ Bir aydınlanma ruhu içinde felaket yalnızdı"” (ss. 64-65).

Tüm şiirlerine gündelik hayatın ayrıntıları, masallar, filmler, diziler, kediler, eşyalar, onda iz bırakan her şey yansımıştır. Hayatla beslediği şiirleri kimi zaman acıyı, kederi, hüznü kimi zaman aşkı, sevdayı, tutkuyu, çoğunlukla hissettiği tedirginliği, öfkeyi, endişeyi ve isyanı dile getirmiştir. Kelimelerle kavgası hiç bitmeyen bir kadın olan Didem Madak, kelimelerin mezarlığındaki bir gece bekçisi gibi onların dirileceği günü beklemiştir. Kelimelere olan aşkı, gösterişten ve ün merakından uzak kalmasını sağlamıştır (Yücel, 2014).

\section{Annesizlikten şair olmak}

Didem Madak şiirlerinde annelik, kadınlık ve ölüm izleklerini etkin bir şekilde kullanır. Bunun nedenini şöyle açıklar: 
Ben annemi çok küçük yaşta kaybettim. Ve herhangi bir kadının gölgesinde büyümedim. Kız çocukla hayat arasında anne, bir tampon vazifesi görür, diye düşünüyorum. Yani anne, kıza hayatı süzerek getirir ve ona kültürel kodları verir. Ve kız hayata bu şekilde hazırlanmış olarak girer, diye düşünüyorum. Bende öyle bir şey olmadı. Çünkü annemi çok küçük yaşta kaybettim ve tek başıma ve kendimce bir perspektif oluşturarak hayata bakmaya başladığımı düşünüyorum. Hayata farklı bakmanın, farklı hissetmenin, insanın içeriden, içerideki gözleriyle görmesinin yazmayı getirdiğini düşünüyorum (Madak, 2015, ss. 55-56).

Kızı Füsun’a yazdığı mektupta belirttiği gibi Didem Madak, “annesizlikten şair olduğu" düşüncesini her dizesine sindirmiş bir şairdir. Bu yüzden, içten içe hüzün dolu olan her şiirinde geçmişe dair olayları anımsarken hep annesine yer verir. Annesinin ölümü onun kırılma noktası olur. Kendi benliğinin farkına varamadan ve hayata anne yardımıyla hazırlanamadan ortada kalmış bir çocuğun çaresizliğini şiirlerinde dışa vurur. Her şiirinde saklamaya çalıştıkça daha da ortaya çıkardığ 1 kendisini anlatır. Gerçekçi anlatımı hakkında bir röportajında dile getirdiği şu satırlar, her şiiriyle özdeşleştiğinin kanıtıdır:

Samimiyet şairin kendi deneyimine, düşünsel sürecine denk düşecek şiiri yazması demek bence. Şiirinin arkasında durabilmesi demek. Bazen özentili, güzel söz söyleme hevesiyle veya can sıkıntısıyla yazıldığı belli olan şiirler okuyorum. Şiire soruyorum o zaman: Hani ya senin şairin nerde? İyi şiir şairinin parmak izi gibidir. Tanırsınız hemen (Bilir, 2012).

Onun yukarıda alıntılanan düşünceleri ve kendi şiirleri göz önüne alındığında; Didem Madak'ın parmak izinin annesi olduğunu söylemek mümkündür. Madak, özne olarak gizlenmediği şiirler yazar ve şiirlerinde anne arketipinin yansımalarına rastlanır. Anne kompleksine güçlü bir şekilde sahip olan bir kişi; annesinin söylediği her şeye karşı duyarlılık gösterir. Annesiyle ilgili olan en ufak ayrıntıya bile önem verir. İçinde annesinin imajı olan hikâyelere, fikirlere ya da olaylara karşı duyarlıdır (Hall \& Nordby, 2016, ss. 36).

Carl Gustav Jung, kızın anne kompleksini anlatırken bu durumu dört başlıkta ele alır. Birincisi dişiliğin aşırı derecede gelişmesidir. Bu durumda dişi içgüdüler, özellikle de annelik içgüdüsü kuvvetlenir ve kendi kişiliği ikincil durumda kalır. İkincisi aşırı gelişmiş Eros’tur. Kızın babaya yönelmesi nedeniyle annenin kıskanılması ve ondan üstün olma isteği su yüzüne çıkar. Üçüncüsü anne kompleksinin Eros’un aşırı gelişimine yol açmadığında yaşanan anneyle özdeşleşme durumudur. Kız, kendi kişiliğini anneye yansıtır ve dişilik özellikleri felce uğrar. Bu kadınlara anneliği, sorumluluğu ve kişisel bağlılı̆̆1 anımsatan her şey onlarda aşağılık kompleksine neden olur. Kompleksle karşılaştıklarında kaçıp sığındıkları yer yine annedir. Dördüncüsü, annenin üstünlüğüne karş1 direnme yani anneye karşı dirençtir. Bu tip olumsuz anne kompleksine örnektir. Annesi gibi olmak istemeyen kız, bir yandan özdeşleşmeye varmayan bir hayranlık bir yandan da anneyi kıskançlıkla reddetmekten ibaret olan Eros'un aşırı gelişimi içerisindedir. Bu 
nedenle, tüm içgüdüleriyle anneyi reddeder fakat kendine ait bir yaşam tarzı kuramaz (Jung, 2012, ss. 26-30).

Anneye dair kompleksler, anne sevgisi ya da sevgisizliği yaşamış çocuklarda ortaya çıkmaktadır. Didem Madak, annesini küçük yaşta kaybettiği için ondaki anne imajı, kompleks şeklinde ortaya çıkmamış; bilinç dışında bulunan anne arketipi aktif hâle gelmiştir. Çünkü anneye olan bağlılık, anne arketipine olan bağlılıktır. Bu bağlılık sonucunda anne arketipinin olumlu özellikleri olan şefkat, yardımlaşma duygusu, olgunluk, üretkenlik ve yaratıcılık kendisinde etkili olmuştur.

Jung (1997), iki türlü arketipin varlığından bahseder: Biri, kendi başına ve kendi içinde var olan arketiptir. Bu arketip, her ruhsal yapıda ancak gizil güç olarak bulunur. Öteki arketip ise, algılanabilir duruma gelmiş yani bilinç alanına girmiş arketiptir (s. 47). Didem Madak'ın şiirlerindeki anne arketipine bakıldığında, ikinci durumun örneklendiği görülür. Yani arketip, algılanabilir duruma gelerek bilinç alanına dâhil olmuştur. Şairin hayatında merkez kişi olan, izleri en ufak ayrıntılarda bile yaşatılan annenin konumu ve şiirlerdeki tezahürü; anne arketipinin izlerini sergilemektedir. Annesizliğin çaresizliği içinde huzur arayışının görüldüğü Didem Madak'ın şiirleri, anne arketipin temel özelliklerini örneklendirmesi bakımından dikkat çekicidir. Bilinç alanına çıkmış olan bu arketipin varlığı sezdirmeler yoluyla değil doğrudan dile getirilmiş ve çoğu şiirde "anne" sözcüğüyle birlikte takip edilebilmiştir.

\section{Grapon Kâğıtları'nda anne arketipi}

Grapon Kâğttlarl'nda; anneye dair göndermelerin bulunduğu şiirler Annemle Ilgili Şeyler, Enkaz Kaldırma Çalışmaları, Çiçekli Şiirler Yazmak İstiyorum Bayım! ve Pollyanna 'ya Mektuplar'dır. Didem Madak'ın yazdığı tüm şiirler içerisinde anne arketipinin izlerini en iyi şekilde yansıtan şiir Annemle İlgili Şeyler' dir.

Annemle İlgili Şeyler şiiri, ilk olarak başlığı nedeniyle "anne”yi merkezî bir konuma taşır. Hayatta olumlu olarak değerlendirilebilecek olan her şeyi anneyle eş değer tutar. Şaire göre merhamet, saflık, masumiyet gibi şiirin içinde geçen her söylemin karşılığ annedir. Annenin gidişi/ölümü ile güzel olan her şey yitirilecektir. Şiirin başında yer alan "Sevgili Anneciğim" hitab1, şiirin sonunda "Anne” sözcüğünün sonuna getirilen ünlem ile tamamlanır. Böylece bir çerçeve içine alınan şiirde; başlangıç ve kapanış sözcüklerinin seçimi sayesinde anne ile başlayan hayat, onun ölümünün ardından her şeyin yitirilmesiyle son bulur (Ünveren, 2016, s. 618).

Annemle İlgili Şeyler şiiri, anne arketipinin izlerini taşıması ve Didem Madak'ın annesiz hayat yolculuğuna 1şık tutması bakımından önemlidir. Şiirin ön plana çıkan bölümleri; şairin “mucize” öldükten sonra taşındığı Muc'1n evinin penceresinden nasıl baktığını, acımasız ölü anne sesiyle nasıl baş edebildiğini ve annesini nasıl özlemle andığını göz önüne serer: "Sevgili Anneciğim, / Binlerce kez açıldım, binlerce kez kapandım yokluğunda/ (...) Şimdi mucizevî bir yerdeyim/ Muc'ın ucuz evinde/ Sanki mürekkebi rutubet olan bir kalem/ Duvarlara hep senin resmini çiziyor/ di'li geçmiş zamanda birçok resim,/ Hep 
gülümsüyorsun/ (...) Hatırlar mısın?/ Mavi saçlı bir tanrı gibi severdim Burdur Gölü’nü/ O göl şimdi içimde kocaman bir anne ölüsü./ (...) Bazen ölmek istiyorum/ Beni yeniden doğurman için/ İri, ekşi bir vişne tanesi gibi./ (...) Yaşasaydın, hayatının ortasına/ Güller yığan bir adam olsun isterdim babam./ Sen bir çocuk romanı annesi ol isterdim./ (...) Şalına sarınırdın toprağa sarınır gibi/ Erken öleceğini biliyordum bana bırakmak için,/ Bu acımasız ölü anne sesini/ (...) NOT: Ölen her kadın için şiir yazdım./ Onları Muc'a evin karşıllğıında verdim/ Çok ucuza./ Artık bütün üzgün oluşlarımın adı:/ ANNE!” (ss. 16-19).

Jung için ruh imgesinin ilk taşıyıcısı her zaman annedir. Daha sonra annenin yerini, olumlu ya da olumsuz anlamda, başka kadınlar alır. Bu çatışma ve normale dönme durumu erkeklerde daha belirgindir, kızlarda ise anneyle özdeşleşme daha kolaydır (Jacobi, 2002, s. 157). Anneyle özdeşleşme, doğmanın en saf ve kusursuz hâlidir. Hem anneyle birlik kurulur hem de ondan ayrı kalınır. Anneyi ve kendini bilerek, doğumdan sonra annenin dışında olmanın verdiği farkındalık duygusu yaşanır. Anneyi bilmek için kendi olmanın, kendi olmak için de anneyi bilmenin gerektiği sonsuz bir döngüdür. $\mathrm{Bu}$ durum: "Bazen ölmek istiyorum/ Beni yeniden doğurman için/ İri, ekşi bir vişne tanesi gibi." dizelerinde beliren "yeniden doğmak için ölmek" isteğidir. Didem Madak'ın hikâyesinde bu istek gerçekleşir. Annesi, kendisi ve kızı şeklinde devam eden döngüde; Didem Füsun'dan, Füsun Didem'den doğar (Konuk, 2015, s. 65). "Beni anneme götürsün bindiğim bütün taksiler” dizesinin yer aldığı Enkaz Kaldırma Çalışmaları'nda, hayat döngüsünün merkezine "Füsun" adını koyar. Bunun nedeni, yaşamın devamlılığını sağlamak için tüm bağlarını koparıp yeniden doğmak istemesidir. İçinde bulunduğu bu döngüyü şu şekilde dile getirir: "Kezzap attı yüzüme sokak lambaları/ Tenekeden bir aydınlıkla kestim/ Hayatla ilgili bütün bağlarımı/ Hazırım ben/ Bir anne ismine bağlamayı her şeyi:/ Füsun..." (s. 37).

Didem Madak, annesinin kaybını Çiçekli Şiirler Yazmak Istiyorum Bayım! adlı şiirinde: "On dört yaşındaydı ruhum bayım/ Bir mermer masanın soğukluğunda yaşland.." diyerek dile getirir. Pollyanna'ya Mektuplar'da ise, annesini ve ona olan özlemini anlatır: "Yolda bavulumu çaldılar/ Bana hediye ettiğin o kırmızı elbise de içindeydi/ Ne güzeldi/ Ben kendime çilek derdim onu giydiğimde/ Bakar bakar anne derdim memelerime/ (...) Annem işte öyle bir kadındı/ Çocuklar gökyüzüne bakar sorardı:/ Aydede orada ne yapıyor anne?/ Annem öldügünde aydede içimde/ Yüzlük bir ampul gibi parçalandı./ Annem işte öyle bir kadındı/ Aşure getiren çocuklara,/ Teşekkür eder gibi yaşadı/ Öldügünde gül resimli bir takvim yaprağıydı" (ss. 64-67).

Grapon Kâğıtları'nda yer alan ve "anne"yi anlatan tüm şiirlere bakıldı̆̆ında, geçmişe dair yaşanmışlıkları bir arada bulmak mümkündür. Tıpkı bir anı defterinin içinden dökülen yapraklar gibi her dizede anneye duyulan özlem ve onun ardında bıraktığı sonsuz boşluk kendisini hissettirmektedir. Bu nedenle, Didem Madak'ın söz konusu şiirlerinde anne arketipinin yansımalarına yer verdiğini, şiirlerinde annesini yaşattığını ve sanki her zaman yanındaymış gibi onunla konuştuğunu söylemek mümkündür. 


\section{Ah'lar Ăgacı'nda anne arketipi}

Ah 'lar Ağacı'nda; Ah'lar Ăgacı, Siz Aşktan N'anlarsinız Bayım?, Müsveddeler ve Paragraf Başı adlı şiirlerde anne arketipinin izleri takip edilebilmektedir. Annemle İlgili Şeyler şiirinde: "Bazen ölmek istiyorum/ Beni yeniden doğurman için/ İri, ekşi bir vişne tanesi gibi." dizelerinde geçen "vişne tanesi"ne Ah'lar A Ğacı'nda tekrar rastlanır. Bu sefer vişne, anneye dair anıların merkezindedir: "İlk üç vişneyi verdiğinde bahçedeki ağaç/ Annem sevindiydi hatırlarım./ Ah demişti./ Ah!/ Üç küçük kırmızı dünya verilmişti sanki ona./ Annem çok sevinmelerin kadınıydı./ Bazen sevinince annem gibi,/ Rengârenk reçeller dizerim kalbimin raflarına./ Annem çok sevinmelerin kadınıydı,/ Sıcak yemeklerin./ Başına diktikleri o taş,/ Ne zaman dokunsam soğuktur oysa./ Ben okşadığımda ama, 1sınır sanki biraz" (s. 24).

Olumlu anne arketipinin yansitıldığ bu dizelerde arketip, simgesel bir anlamla ifade gücü kazanır. Bilinçli tasavvurlar olmayan arketiplerin aracısız olarak ortaya çıkmaları zordur. Temelde tek bir motifin temsilî resimlerini oluşturma eğilimi gösterirler. Yine de bu temsilî resimler, temel yapıları değişmeksizin ayrıntılarda çok büyük farklılıklar gösterebilir (Jung, 2009, s. 67). Bu görünümde anne, doğurganlık ve bereketi temsil eden durumlarla eşleştirilir. Kendisine "üç küçük kırmızı dünya" verilmiş gibi hissetmesi, gelişim ve verimlilik sağlayan anne arketipinin iyi yönlerini örneklemektedir.

Arketipler, hem imge hem de duyguları içerir. Bu iki yön bir arada bulunuyorsa bir arketipten söz edilebilir. Tek başına bir imge, özel bir anlamı olmayan bir kelime temsilinden ibarettir. Eğer o imge, bir duyguyla yüklüyse o zaman bir gizem kazanır ve dinamik duruma gelir (Jung, 2009, s. 96). Didem Madak'ın şiirlerindeki anne arketipinin sevgi, özlem, acı ve hüzün gibi duygularla yüklü bir şekilde kullanıldığı görülür. Anneye

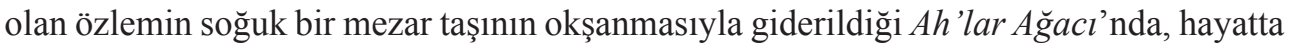
olmamasına rağmen bir annenin desteğinin hissedilebileceği ve yaşamı sürdürebilmek için gerekli olan maddi bir ihtiyacı nasıl karşıladığı ya da karşılayamadığı şu şekilde dile getirilir: "Kuyruk sallardı,/ annemden kalma maaşım/ her üç ayın sonunda" (s. 27).

Ölümün soğuk nefesinin hissedildiği ve insanın annesini kaybetmenin ne demek olduğunun anlatıldığı diğer bir şiir Siz Aşktan N'anlarsınız Bayım? başlı̆̆ını taşır. Kendinden emin bir kadının başkaldırısı niteliğinde olan bu şiirde; yalnızlık, yokluk ve ölüm duygusu bir arada işlenir: "Kimi gün öylesine yalnızdım/ Derdimi annemin fotoğrafına anlattım./ Annem/ Ki beyaz bir kadındır/ Ölüsünü şiirle yıkadım./ Bir gölgeyi sevmek ne demektir bilmezsiniz siz bayım/ Öldüğü gece terliklerindeki izleri okşadım” (s. 38).

Müsveddeler şiirinde: "Annemin temizlik günleri gibiyim/ Yorgun, solgun ve beyaz" (s. 59) diyerek insanın yaşarken dikkat etmediklerine ya da önemsemeden geçtiği ayrıntılara bir kez daha dikkat çeker. Sonradan farkına varılan her gerçek gibi, hayatın da kendi akışı içerisinde insanları yorgun düşürdüğüne ve bunun daha sonra anlaşılabildiğine değinir. Tıpkı bir defterin yapraklarının sararıp solması gibi insanın hayatı da her yeni günde, bir nebze daha eskimektedir. Paragraf Başı şiirinde bu solma durumu, annesinden kalan şiir defteriyle geçirdiği günlerin defterde nasıl bir iz bıraktığı üzerin- 
den anlatılır: "Annemin bir şiir defteri vard1/ Yaprakları gitgide sarard1/ Hep sararan bir şey olarak kalmışsın aklımda./ Sanırdım/ Bu dünya karaciğerinden hastadır/ Sanırdım/ Boyama sarışın bir kadındır zaman/ Hep hayatını anlatır” (s. 71).

Ah'lar A ğacı'nda yer alan ve anneye atıfta bulunulan şiirlerde yalnızlık, yokluk ve ölüm duygusunun ön planda yer aldığı görülür. Hayatın getirdiği sıkıntıların, sadece annenin yerine konan soğuk bir mezar taşına anlatmanın zorluğu ve ardında bıraktığı izlere bile muhtaç olmanın neden olduğu üzüntü tüm dizelerde canlandırılmıştır. Böylece hem imge hem de duygu yönü bulunan arketipsel bir içerik kullanılmıştır.

\section{Pulbiber Mahallesi'nde anne arketipi}

Pulbiber Mahallesi'nde; Büyümü̧̈ Çocuk Şiiri, Gecenin Çekmecesi, Poşet Süt, Bizden Başkalarına, Onlara, Çocuklara, Karşıllkssız Hayat ve Vaziyet başlıklı şiirlerde, aynı kitapta yer alan ve yazdığ 1 son şiir olan 128 Dikişli Şiir'de, anne arketipinin farklı görünümleri ile karşılaşmak mümkündür.

Anne arketipinin ana çizgilerini ortaya koyan Jung'a göre, yaşamın en unutulmaz, en duygulu hatıralarını kapsayan, tüm gelişim ve değişimin gizemli kökeni anne sevgisidir. O sevgi; eve dönme, barınma, her şeyin başladığı ve bittiği uzun bir sessizlik anlamına gelir. Başlangıçta kişiye yabancı olsa da içten içe bilinir; sevgi dolu, şefkatli, neşeli ve bitmez tükenmez bir yaşam vericidir (Jung, 2015, s. 135).

Anne arketipinin olumlu tüm yönlerine şiirlerinde yer veren Didem Madak için anne sevgisi ve özlemi, onun verimliliğini sağlayan önemli bir dinamik hâlini almıştır. Annesinin yaşam verici gücünü şiirlerinde dile getirdiği özlemiyle harmanlayan şair, annesinin adı olan "Füsun" sözcügünün büyülü anlamından yola çıkarak farklı bir atmosfer içinden okuyucuya seslenir. Çünkü şair için şiir, değiştiren ve dönüştüren bir sihirdir. Hayaller ve rüyalar, yazma sürecindeki Didem Madak'1, şair sezgisiyle birlikte bu büyünün içine çekmiştir. Annesi Füsun Hanım'ın adından da yola çıkarak -özellikle Pulbiber Mahallesi kitabında daha da belirgindir bu- füsun, efsun, büyü, sihir sözcüklerinin etrafında dolanarak şiirdeki arayışını sürdürür (Bilir, 2015, s. 26).

Jung'a göre, insana bağlı olmayan bilinç dışının merkezini ve güç alanını arketipler oluşturur. Bilinç dışında biriken içerik, bilinçli bir bilginin erişemeyeceği gözle görülmeyen bir düzene girer. Bu düzen içerisinde yolu çoğunlukla saptırılmış, görünüş ve anlamı değiştirilmiş olabilir. Bilinç dışının bu iç düzeninden yararlanmayı bilmek ve arketiplere bilinçli bir şekilde yaklaşmak, farklı çözümleme çalışmalarının yapılmasına olanak sağlar. Arketip imgesinin biçimi cılızsa ya da iyi tanımlanmamışsa, ortak bilinç dışının derinindeki bir katında bulunuyor demektir. Bu katmanda simgeler, bireysel bir içerikle dolmamışlar yani bireysel yaşantı ile ayrışmamışlardır. Eğer arketip kişisel ve güncel ise, kullanılan arketip figürü de o oranda ayrıntılı ve belirgindir. Yine de bilinç dışında yer alan arketiplerin gizil güç olarak kullanılması için onun yansımalarını çözümlemek ve onu bilinç düzeyine çıkarmak gerekir. Bu aşamada, arketipin doğrudan ifade bulmasının dışında arketipik bir içeriğin kendini istiare ile açığa çıkardığı da görülür (Jung, 1997, s. 48-52). 
Didem Madak'ın şiirlerinde doğrudan anne sözcüğüyle birlikte takip edilebilen anne arketipi, annesine yönelik seslenişlerinde kimi zaman istiare şeklinde ortaya çıkar. "Büyü" sözcügüule "büyümek" eylemi dönüşümlü bir anlama gelecek şekilde kullanılırken "Füsun” adına bol bol yer verilir. Pulbiber Mahallesi'ndeki Büyümüş Çocuk Şiiri'nde ve Gecenin Çekmecesi'nde bu durum görülür. Büyümüş Çocuk Şiiri'nde bu kullanım şu şekildedir: "Artık büyü diyorlar bana/ Ekmeğini salatanın suyuna banma/ Ben artık büyüyüm Füsun/ (...) Ben yürümüyorum Füsun, cadde yürüyor/ (...) İmgelerle yer değiştiriyorum Füsun" (s. 15- 16). Gecenin Çekmecesi'nde ise, bu çift anlamlı kullanımın hüzünlü bir tonla birleştirildiği görülür: "İnsanlar öldüler, hep öldüler, bir gün öldüler/ Anlaşılmaz!/ (...) İnsanlara uyanmalarını kim söylüyor Füsun/ Kim sabah oldu diyor onlara?/ (...) Bilirsin işte Füsun gidişinden bu yana/ Hüzün sektöründe bilfiil yirmi üç sene görev yaptım!/ İnfaza götürürken bari üstbenlerim/ Gözüme bir gökkuşağı bağlasalar./ Bir gece kalkıp bütün 1şıkları yakacağım Füsun/ Şiirime 1şıktan bir nokta koyacağım!” (s. 17).

Şiirde geçen 'üst ben' ifadesi, psikanalizin kurucusu olan Sigmund Freud tarafindan şekillendirilen yapısal kişilik kuramını akla getirir. 'Üst ben', içgüdüsel doyumlarda kişi üzerinde sınırlamaya giden güçtür. 'Ego’yu gözetim altında tutan ‘üst ben', onu yargılar; tıpk1 anne ve baba gibi verdiği cezalarla onun gözünü korkutur. 'Üst ben’, anne ve babanın yalnızca sertliğini, ciddiliğini ve onların sevecen kaygılarını değil; bunların yanında yasaklayıc1, bask1 altında tutucu rollerini de benimsemiş gibi görünür. Bu nedenle bir idealin temsilidir (Freud, 2014a, ss. 92-94). Anne ve babanın koruyuculuğundan uzak bir hayat geçiren şair için 'üst ben', sadece infaza götürebilecek ve çektiği sıkıntılara son verebilecek olan kişidir.

Poşet Süt şiirinde, çocukluğa has mutlu zamanları dile getirir. Annesinin kızmayacağı eylemlerde bulunan iyi bir çocuk olduğu dönemi, kendisini tıpkı bir kedi gibi görerek anlatır: "Süt deyince hep müstehcen şeyler geliyor aklıma/ Şiirde tam pansiyon kalıyorum Füsun/ Tonton kediler var bu mahallede hepsi de yazılıyor bana./ Ben sütleri hiç dökmüyorum Füsun/ Kediler âleminde raconsuz bir davranıştır zira" (s. 18).

Pulbiber Mahallesi, modern insanın hayata karşı çaresizliğini işler. Hayat mücadelesi içinde yer alan şair; ne kadar büyüse de, çocukluğuna duyduğu özlemi bastıramaz. Bu özlemin izleri tüm kırılganlığı ve isyanlarıyla kitaptaki şiirlere yansır. Öte yandan, dilsel anlamda ciddi bir hâkimiyet kurduğu çok sayıda şiire de yer verir. Örneğin Poşet Süt şiirinde mükemmel bir şiir yapısıyla karşılaşılır. "Büyümek” fiili “büyü”, "büyüyüm” gibi sözcüklerle dilsel ve sessel çağrışımları işaretler. Şairin sözcüklerle kurduğu "büyülü” anlam dünyasını gün ışığına çıkartarak masalımsı bir atmosfer oluşturur (Kahyaoğlu, 2007).

Büyümüş Çocuk Şiiri ve Gecenin Çekmecesi başlıklı şiirlerinde yer verdiği, "Füsun" sözcüğünün büyülü anlamından yola çıkarak "büyü” sözcügüuyle "büyümek" eylemini bir arada kullandığı ifadeler Poşet Süt şiirinde şu şekilde yer alır: "Bana artık büyü diyorlar/ Kar tanrı kokuyor oysa Füsun, bilmiyorlar./ (...) Artık büyüyüm Füsun/ (...) Eriyorum Füsun/ (...) İsminden ismimle doğduğuma inanıyorum Füsun/ Bu inanç hiç bitmiyor/ (...) Küstüğümde gözlerinden öpebilmek için dünyanın Füsun/ İsmimle 
doğduğuma inanıyorum isminden/ Artık başkalarına yalnızca komik rüyalarımı anlatıyorum./ Doğururken geçenlerde/ Çok sancım vardı, bişey olmadı/ Bana bişey olmaz, artık.../ Büyüyüm ben Füsun" (s. 18-19).

"Füsun" adıyla büyüyle büyüyen ve hayatın zorluklarını göğüsleyen şair, yine de bir çocuk gibi defterini annesinin kaplamasını ister. Ancak bu masum isteği, kardeşini avuturken bir anlamda anne rolüne bürünmesiyle kaybolur: "Annemi ziyaretten dönerken/ Sarılık olurdu esmer kardeşim, sarışın oldum diyerek./ Ben de sarılayım, sarışın olayım isterdim./ Annesi ölmüş çocuklardan tarifler bulaştı bana./ Kelimeler ölsün istemem bu yüzden/ Tarifler sırasında beklerken/ İstemem içimde ezilsinler” (s. 28).

Annesinin ölümüyle yüzleştiği hayatında kaleme aldığı Bizden Başkalarına, Onla$r a$, Çocuklara başlıklı şiirinde: "Annemin ölümünü eskiciye satacaktım/ On mandal karşılı̆̆ında.” (s. 32) diyerek ölümün dayanılmaz ağırlığını hafifletir. Karşıllksız Hayat’ta: "Çocukken elektriklerin kesilmesini isterdim/ Annem masal anlatırdı o zaman./ Çünkü sahibini görmediği sesleri şiir sanır insan." (s. 58) diyerek annesinden dinlediği masalların içerisine şiir katar. $\mathrm{Bu}$ şiirini de aile fertlerinin adıyla bir oyun esnasında tamamlar: "Kelimelerle beş-taş oynayan bir çocukken belki/ Annemin adını tekrarlardım/ Kardeşimin adını/ Kendi adımı/ Belki babamın bile adını" (s. 59).

Vaziyet şiirinde, bir çocuğun gerçek hayatta yaşadığı kimi zaman da huzursuzlukla takip ettiği bir veli toplantısına götürür annesini. Fakat bu veli toplantısını manevi bir âlemde gerçekleştirerek bunun da sadece şiir dünyasında olabileceğini şu şekilde dile getirir: "Annem gidip sorsun bari okuldaki durumumu tanrıya/ Kızınız öfkesi koşunca yakalayamıyor hanfendi/ Kalbi delik, dikizliyor durmadan hayatı ordan./ Kızınız lekelere peygamber oldu hanfendi/ Çarmıhı gevşemiş, çivi arıyor/ Kızınız kendini limon küfü sanıyor karıncalara karşı/ (...) Kızınız mânâyı fazla zorluyor/ Terkibinde takriben 1503 litre tuz ruhu var./ Hangi mânâ dayanır aside hanfendi, eriyor./ Olmuyor hanfendi olmuyor/ Sizin bu kızınız var ya kendini yangın kovası sanıyor/ Siz orda uyuyun hâlâ./ Dünyamızın üstünde bütün ruhlar uyurken/ Annem uyandırılıyor uykusundan/ Üzgün dönüyor hep cennete veli toplantısından./ Şiir icabı bunlar hep, gerçek hayatta olmuyor./ İyiyim falan diyorum sana ama/ Bunlar hep sen yanımda olmadığından" (s. 105).

Annesinin hayaliyle yaşadığı, onunla konuştuğu, "Füsun" adıyla büyüdüğü tüm şiirlerinin ardından yazdığı son şiir olan 128 Dikişli Şiir'de, kendisinin de anne olduğunu haber vererek bu hissin yarattığı mutluluğu dile getirir: "Füsunun yeşil ela gözleri var/ Ve pembe plastik fincanı ile kahve getirişi var/ Ve bana anne deyişi var/ Benim pembe fincandan pembe kahve içişim var/ Bu kahveleri seviyorum ahbap/ İçimi pembe bulutlar kaplıyor/ Şekerli ve tatlı bir biçimde havalanıyorum” (s. 111).

$\mathrm{Bu}$ mutluluğun ardından gelen kaybetme korkusu ve kızını tıpkı kendi gibi hayatta yalnız bırakacağı endişesi de şiirde yer bulur. Didem Madak'ın yazdığı son şiir olması bakımından bir çeşit veda niteliği de taşır. Hayatının özeti gibi olan satırlar şu şekildedir: "Doğdum, doğurdum/ Bir insan nasıl büyüyor gördüm/ Hayatta kalmak için/ Ve hayatta kalmanın yanında/ İnandım şiir bir gevezelikti/ Şimdi 128 harfli bir şiir var karnımda/ Satırlar artık bomboş/ Karnımda hissiz bir şiir var/ Içiimde durmadan bölünen şiirler/ Bir- 
likte yok olacağımız şiirler/ Birlikte unutulacağımız şiirler/ Hiç borcu olmamış şiirler/ Ve bu yüzden çok acıyan şiirler" (s. 113).

\section{Sonuç}

Bu çalışmada, edebî eserlere yönelik farklı inceleme ve çözümleme çalışmalarına imkân tanıyan arketipsel eleştiri yöntemi, Didem Madak’ın şiirlerine uygulanmıştır. Uygulama sonucunda, Didem Madak'ın tüm şiirlerinde anne izleğinin takip edilebildiği görülmüştür. Doğumdan itibaren başlayan ve bireysel yaşantıyla şekillendirilen anne arketipi, her bireyde bulunmaktadır, ancak bilinç dışında bulunan anne arketipinin bilinç düzeyine çıkması her bireyde farklı şekillerde gerçekleşmektedir. Didem Madak’ta bu dışa vurum, şiir üzerinden gerçekleşmiş ve her dizesinde annesizliğin acısını anlatmıştır.

“Annesizlikten şair oldum.” diyen Didem Madak; küçük yaşlarda annesini kaybeden ve kırklı yaşlarının başındayken henüz üç yaşındaki kızını ardında bırakarak hayata gözlerini yuman bir şairdir. Hayatı boyunca anne yoksunluğunun acısını çeken şair, annesizliğin ortaya çıkardığı her duyguyu şiirlerine yansıtmıştır. Bu nedenle de, anne arketipinin tüm izlerini onun eserlerinde görmek mümkündür. Acılarını, yazdığı şiirlerle dindiren Didem Madak'ta anne arketipi; şefkat, yardımlaşma duygusu, üretkenlik ve yaratıcılık şeklinde ortaya çıkmıştır. Yaratıcılığını şiir yazarak gösteren şair, şiirlerini üç kitapta toplamıştır. İlk kitabı olan Grapon Kâğıtları'nda; annesinin eksikliğini, geçmişe dair yaşanmışlıklarını anlatarak dindirmeye çalışmıştır. Ah 'lar A ğacı'nda, hayata karş1 "ah" etmiş; bu iç çekişini yalnızlık, yokluk ve ölüm duygusuyla harmanlamıştır. Pulbiber Mahallesi'nde; annesinin adı olan "Füsun"u, "büyü” sözcüğü ve "büyümek" eylemiyle birlikte kullanarak masalsı bir atmosfer oluşturmuştur. Son yazdığı şiir olan 128 Dikişli Şiir ile şiirlerine ve hayata veda etmiştir.

Didem Madak'ın hayatına ve yazı serüvenine bakıldığında, yazdığı şiirlerle hayatı arasında bağ kuran ve bilinç dışının tüm içeriklerinden yararlanan bir şair olduğu görülür. Zengin bir malzeme sunan bilinç dışından seçtiği olayları ya da sözcükleri şiirlerinde kullanarak kendi hayatı üzerinden başka hayatlara seslenmiştir. Ortak bilinç dışı içeriklerini oluşturan arketipleri kullandığı için de, şiirlerinde herkesin kendisinden bir şeyler bulmasını sağlamıştır. Bireysellik içindeki evrenselliği işaret eden arketiplerden olan anne arketipinin Didem Madak'ın şiirlerindeki yansımaları, edebî eserlere uygulanacak olan farklı çözümleme yöntemleriyle yeni bulguların elde edilebileceğini göstermiştir. Bu nedenle, aynı ya da farklı bir eser üzerinde yapılacak olan arketipsel inceleme çalışmaları, farklı katmanlardan oluşan eserlerin yorumlanmasına katkı sağlayacaktır.

\section{Notlar}

1 Didem Madak, Grapon Kâğıtları, Metis, İstanbul: 2017. (Metin içerisindeki alıntılar, kitabın bu baskısından aktarılmıştır.)

2 Didem Madak, Ah'lar A $\breve{g} a c ı$, Metis, İstanbul: 2017. (Metin içerisindeki alıntılar, kitabın bu baskısından aktarılmıştır.) 
3 Didem Madak, (2016). Pulbiber Mahallesi, Metis, İstanbul: 2016. (Metin içerisindeki alıntılar, kitabın bu baskısından aktarılmıştır.)

\section{Kaynaklar}

Alp, R. (2012). Türkçe şiirde "kadın” şairlerin poetikalarının karşılaştırmalı olarak incelenmesi. (Yayınlanmamış Doktora Tezi). İhsan Doğramacı Bilkent Üniversitesi Ekonomi ve Sosyal Bilimler Enstitüsü, Ankara.

Bahadır, A. (2010). Jung ve din. İstanbul: İz.

Bilir, M. (2015). Didem'den Efsunlu İzler. S. Zelyüt (Ed.), Didem Madak’l okumak (ss. 23-32). İstanbul: Metis.

Freud, S. (2014). Haz ilkesinin ötesinde/ben ve id. (A. Babaoğlu, Çev.) İstanbul: Metis.

Hall, C. S. ve Vernon J. N. (2016). Jung psikolojisinin ana çizgileri. (E. Gürol, Çev.) İstanbul: Cem. Jacobi, J. (2002). C. G. Jung psikolojisi. (M. Arap, Çev.) İstanbul: İlhan.

Jung, C. G. (1997). Analitik psikoloji. (E. Gürol, Çev.) İstanbul: Payel.

Jung, C. G. (2012). Dört arketip. (Z. Y1lmazer, Çev.) İstanbul: Metis.

Jung, C. (2015). Feminen-dişilliğin farklı yüzleri. (T. V. Soylu, Çev.) İstanbul: Pinhan.

Konuk, O. (2015). Mahallenin Kayıp Kızı: Didem Madak Şiirinde Üç Benlik. S. Zelyüt (Ed.), Didem Madak'ı okumak (ss. 61-70). İstanbul: Metis.

Madak, D. (2015). Son Söz. S. Zelyüt (Ed.), Didem Madak'ı okumak (ss. 355-358). İstanbul: Metis.

Madak, D. (2016). Pulbiber mahallesi. İstanbul: Metis.

Madak, D. (2017a). Ah 'lar ağacı. İstanbul: Metis.

Madak, D. (2017b). Grapon kâğıtları. İstanbul: Metis.

Sambur, B. (2005). Bireyselleşme yolu-Jung'un psikoloji teorisi. Ankara: Elis.

Ukray, M. (2015). Jung psikolojisi. Ankara: Yason.

Ünveren, D. (2016). Muc'un ucuz evinde mucizenin ölümü: Didem Madak'ın annemle ilgili şeyler adlı şiiri üzerine söylem çözümlemesi. Turkish Studies, 11/15, 609-632. doi: 10.7827/ Turkish Studies. 9877.

Yücel, Ş. (2011, 30 Temmuz). Hayatını şiire tercüme etti. Cumhuriyet, s. 16.

Yücel, Şükran. (2015). Didem Madak: Şiire Karşı Şiir. S. Zelyüt (Ed.), Didem Madak’ı okumak (ss. 99-107). İstanbul: Metis.

\section{Elektronik kaynaklar}

Bilir, M. (2012). Didem Madak'la söyleşi. Erişim tarihi: 25.01.2018, http://www.edebiyathaber.net/ didem-madakla-soylesi/.

Kahyaoğlu, O. (2007). Modern masal tadında şiirler. Erişim tarihi: 24.01.2018, http://www.radikal. com.tr/kitap/modern-masal-tadinda-siirler-859399/.

Yücel, Ş. (2014). Bir şair kaç kere ölür? Erişim tarihi: 25.01.2018, http://www.artfulliving.com.tr/ edebiyat/bir-sair-kac-kere-olur-i-1238. 